\title{
サクションロール素材の残留応力と加工性
}

大平洋製鋼㑣) 瀬尾 省逸，高橋 博彦

\section{Residual Stress and Machinability of Pipe Materials for Suction Roll Shells}

\author{
Shoitsu Seo and Hirohiko Takahashi \\ Pacific Steel MFG, Co., Ltd.
}

\begin{abstract}
Suction hole drilling decreases Residual stress of Pipe materials quite a lot, so a residual stress level of working Suction roll is very low. Stress relief occurs at the drilling depending on increasing of drill holes. Therefore, ununiform drilling makes a trouble like as roll distortion because of ununiform stress relief.

Good machinability of pipe materials are important for making good Suction rolls. Forged materials are specified in uniform and defects free structure, therefore, forged pipes are the better materials than cast pipes in order to drill the suction holes.

New materials need not noly good corrosion resistance and high fatigue strength but also good machinability. If there is a confused suction hole pattern, effective fatigue strength decreases depending on stress concentration.

To use the technical data of a material for designing the Suction rolls, machinability is the most important characteristic of the pipe material.
\end{abstract}

Keywords : Residual stress, Sachs method, Ring cut method, Drillinability

2 Phase alloy, Corrosion resistance, Stress concentration

\section{1.はじめに}

サクションロールは弱い腐食雲囲気のもとで引張り 一圧縮の繰返し応力を受け，1秒間に 6 回程度の速度 (最高の場合)で回転するロールである。それ故に, ロー ル用素材に要求される性質としては，(1)耐食性(2)高疲 労強度の 2 点がある。薄肉パイプの形状をしているこ の材料は, 一定の負荷応力下で長時間使用された段階 で折損したという事故例が多数報告されている ${ }^{1), 2)}$ 。従 来の鋳造系ロールの折損原因として著者ら ${ }^{3)}$ は内在し ている素材の欠損を起点とする疲労破壞であるとの報 告をしているが，他の報告は(1)腐食説(2)残留応力説の 2 説に大別され，それぞれ結論に結び付く有力なデー ターを示している。

Thompson ${ }^{4)}$ はサクションホールの周辺が腐食し, 応力集中源として作用している状況を示している。

Castillo ${ }^{5)}$ は腐食疲労強度を改善する方法として残
留応力を低減することが対策として有効であるとして いる。また, Hiraishi ら ${ }^{6}$ は材料開発の方向として, 残 留応力の低減対策が必要であると主張するとともに, 耐食性のよい高 $\mathrm{Cr}$ 系の材料を利用し, 極端に残留応 カのレベルを下げる熱処理を採用した材料を開発，利 用している。

しかしながら，折損そのものは最終的には疲労破壊 である点は共通していると思われる。このような解析 に基ずき，耐食性のよい高 $\mathrm{Cr}$ 系の材料が利用された り，特殊熱処理を採用できる材料が利用されている。

一方, サクションロールの製造工程では材料の機械 加工性が実用上極めて大切な特性である。すなわち, サクションホールの穴明け加工の際, 加工性の悪い材 料ではドリルの折損やパターンの乱れが起こり易い。 加工むらにより, パイプ自身が加工後に変形し, ロー ルとして使用できなくなったり，乱れたパターンが応 力集中源として作用し，サクションロールの疲労破壊 
が起きる直接原因になることもある。

ところで，サクションロールが使用不可能となるの は，折損事故によるものであり，著者の行った鋳造系 ロールに関する 15 例の折損事故原因調査によると,い ずれも素材に内在した欠陥を起点として多数の微細な 疲労クラックが発生し, 材料の有効断面積の減少によ り疲労破壞が急速に進行したために折損する7)。した がって, 優れたサクションロール用素材としては, 高 い疲労強度が条件であるが, 無欠陥な素材で造られた ロールに必要な疲労強度はドリル穴の応力集中係数= $4.0^{8)}$ を考虑すると, ほとんどのロールは $10 \mathrm{~kg} / \mathrm{mm}^{2}$ 程度以下の発生応力が採用されている。現在多用され ている素材の中には腐食疲労強度の值として $20 \mathrm{~kg} /$ $\mathrm{mm}^{2}$ のものも存在しているが, それらの材料において も折損事故が発生しているという事実は, もっと正確 に議論されなければならないと考える。

本報告はサクションロール用素材に要求される条件 として, 残留応力ならびに機械加工性をどのように評 価すべきかについて解説するとともに，これらの特性 を改良した新材質の特性について紹介したものである。

\section{2. サクションロール素材における残留応力の}

\section{挙動}

残留応力は素材が熱処理される際の冷却過程におい て, 表面と内部の温度差が原因で発生する。したがっ て, 冷却速度が大きいほど冷却途中の温度差が大きく なるために残留応力の絶対值は大きくなる。

通常のステンレスでは耐食性を改善するため, 溶体 化処理という高温加熱とそれに続く急冷処理が必要で, このために残留応力はどうしても高くなる。この対応 としては, 急冷処理の後に焼き戻し加熱ができる成分 を持ったステンレス鋼を使用することが必要である。

ここでは, 最も高い残留応力を発生する熱処理を施 した素材から制作されるサクションロールには，どの 程度の応力が残留するかについて調查した。

\section{1 残留応力の挙動を知るための実験}

熱処理で大きな残留応力が発生したサクションロー ル素材に穴明け加工を行った場合についてモデル実験 を行った。実験の条件は表 1 の通りであり, 穴明けパ

表 1 実験の条件

\begin{tabular}{l|l}
\hline 素材寸法 & $\phi 124 \times \phi 100 \times 210$ \\
\hline 素材材質 & SUS 304 \\
\hline 熱 処 理 & $1,000^{\circ} \mathrm{C} \mathrm{WQ}$ \\
\hline ドリル径 & $\phi 4$ \\
\hline
\end{tabular}

$\bigcirc 0$

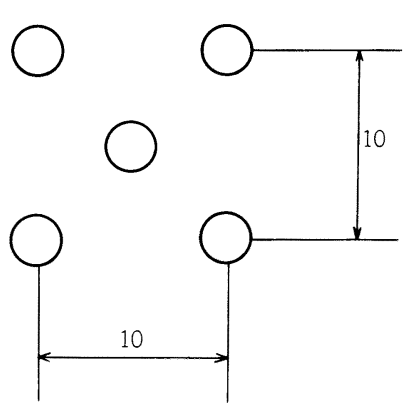

内径開口率 $31 \%$ 外径開口率 $25 \%$ ドリル $4 \phi$

図 1 穴明けパターン

ターンは図 1 に示す正方形モデルとした。

素材の SUS 304 材は以前クーチロールに使用され た代表的なステンレス鋼であり，モデルロールの内径 側での開口率は約 $31 \%$ とした。

\section{2 実験方法}

残留応力の測定はSACHS 法 (内層除去法) と RING CUT 法の代表的な 2 つの測定法によった。実 験の手順は図 2 に示すように, 同一の熱処理をした 2 本のパイプを使用し, 穴明けにより解放された残留応 力の量を測定するものである。

図 3 は焼入れ熱処理直後のパイプの残留応力の分布 状態を示したもので, 内径側で $+7 \mathrm{~kg} / \mathrm{mm}^{2}$, 外径で $-12 \mathrm{~kg} / \mathrm{mm}^{2}$ の值となっている。この值は実用サイズ のオーテスナイト系のパイプで測定された場合のもの と極めて良く一致している。写真 1 は図 1 の穴明けパ ターンにより全面に穴明けを実施したミニチュア・サ クションロールと, 応力測定用に糊付した静歪み測定 用ゲージを示したものである。

図4 は 2 本のパイプのそれぞれの端面から採取した リングにより, 円周方向の残留応力を測定した結果か ら残留応力の分布状況を予測したもので，2本のパイ プがほほ同一の残留応力値を持っていることが分る。

図 5 は穴明けの開始から終了までの間にパイプが変 形していく様子を示したもので, 残留応力の開放が穴 明け量の增加, あるいは位置に依存して進行している ことが分る。この歪みの変化量から，…イイプが変形 した様子は図中の参考図であり $\cdots$, 径の増大と長手方 向の縮みとして残留応力の開放の効果が現われたこと を現している。

図6は穴明けしたパイプに対して, SACHS 法によ り残留応力を測定した結果を示したもので, 穴明けさ れたことにより全体の残留応力は最内層付近でわずか に高いプラスの応力を残す以外は $1 / 5$ 程度に減少する 
1)

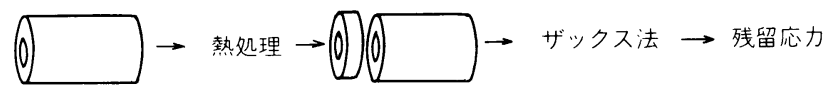

$\phi 124 \times \phi 100 \times 210 l$

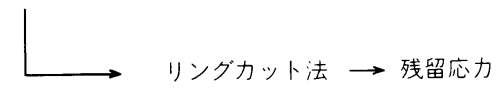

2)

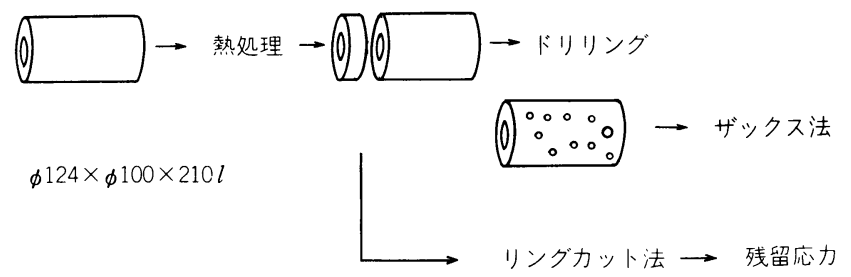

図 2 穴明けによる残留応力の変化の実験手順
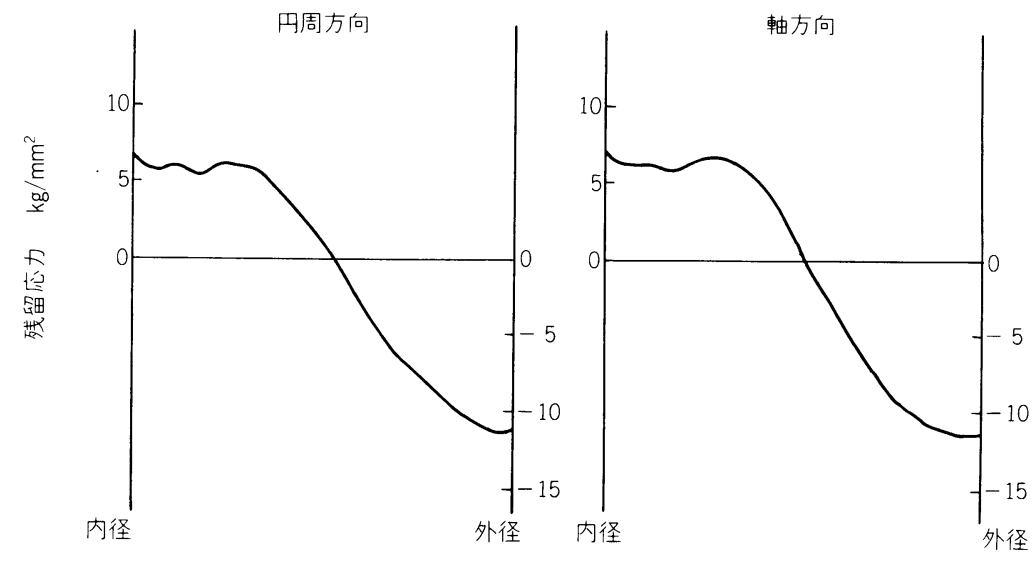

図 3 ミニチュアパイプ材のザックス法による残留応力分布

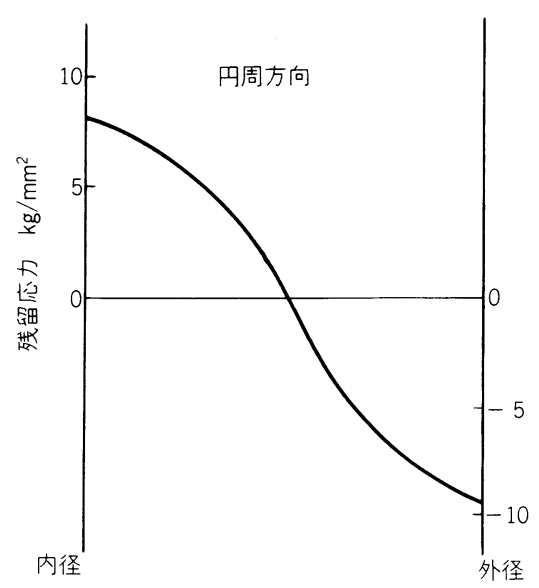

図 4 ミニチュアパイプ材のリングカット法に よる残留応力分布

\section{ことを示している。}

パイプ素材をドリル加工する過程で, パイプ材の残 留応力は開放される方向に変化し, 約 $31 \%$ の開口率の 場合には残留応力の絶対値は $1 / 5$ 程度に減少した。こ の事実は実際に稼動しているサクションロールでは極 めて低いレベルの応力しか残存しない事を示している。 さらに, サクションロール材にとって残留応力が問題 になるのは, ドリル加工の途中に残留応力の開放と同 時にロールの寸法変化が発生している事である。

したがって, 素材メーカーが留意しなければならな いことは, 機械加工する際, いかにスムーズに全面を 均一な条件で実施できる材料とするかである。

ドリル穴加工により残留応力は減少するので，これ まで“破壞の原因は残留応力である”とする残留応力 説で言われていた応力は加工後の応力ではなくパイプ 素材そのものの残留応力が評価されていたものと考え 


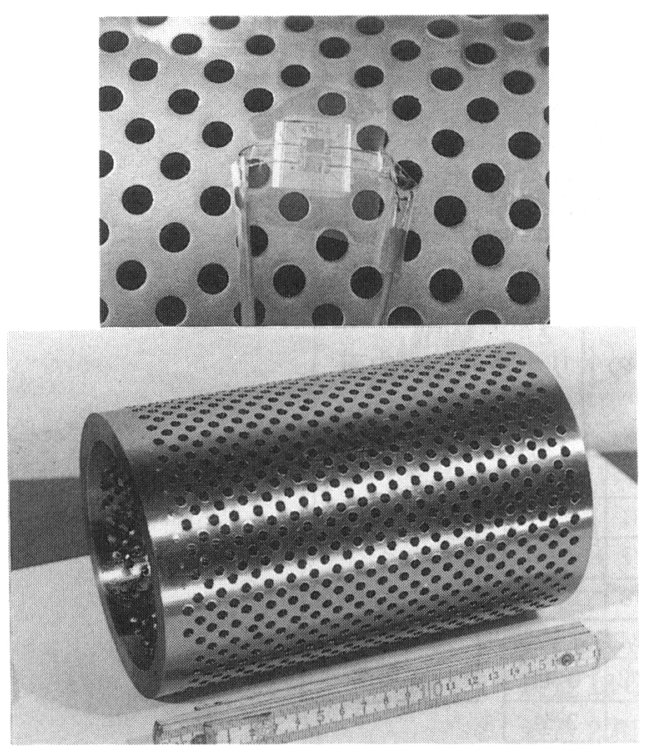

写真 1 穴明けを実施したミニチュアロール の外観
られる。この実験結果は, ドリル加工されたサクショ ンロール材の段階での残留応力は可なり低いことを示 しており, 残留応力が応力腐食あるいは直接疲労に関 与すると考えることは極めて困難であると言える。

ドリル加工の表面においては加工硬化の現象もある が, この加工層はサクションホールの全面に存在し, しかも $0.3 \mathrm{~mm}$ 程度の厚さである ${ }^{10)}$ 。この加工面にお ける残留応力を X 線法により測定した結果, $+3 \mathrm{~kg} /$ $\mathrm{mm}^{2}$ の值であった。この加工硬化層はサクションロー ルの表面付近における腐食の進行, あるいはマイクロ クラックの発生に対して作用する可能性を残している ものの, 多くのサクションロールの折損事故がロール のほぼ中央で起きているという事実を説明できない11)。

ドリル加工表面における加工硬化現象は, 全てのサ クションホールに共通の条件であるため, 応力腐食の 原因に成り得るとすれば全面が腐食する可能性がある。 しかしながら, 写真 2 が示すようにツイストドリルで 加工された, $13 \mathrm{Cr}$ 系の比較的粗い仕上げ面の約 10 年 使用後に折損したロールについてはホール内面に全面 腐食を観察することはできなかった。部分的に発生し ている腐食孔は大部分が鋳造欠陥，あるいは非金属介 在物を起点としている事も観察されている3)。

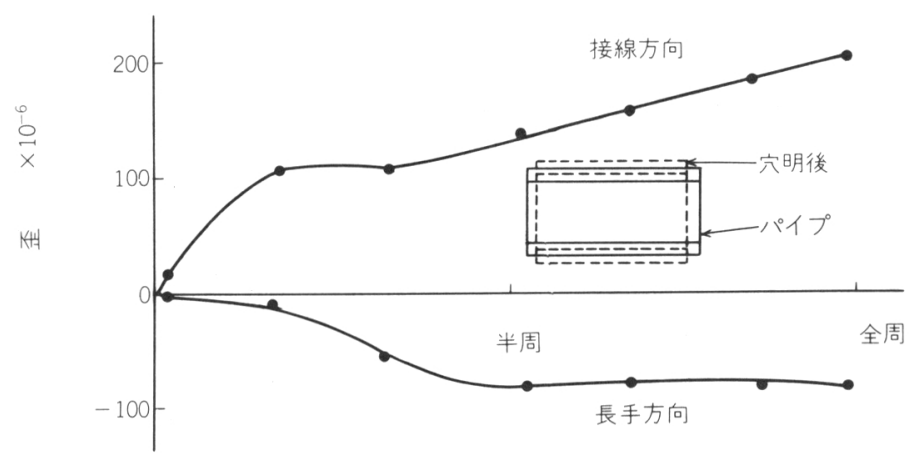

図 5 穴明け途中におけるパイプ材の変形

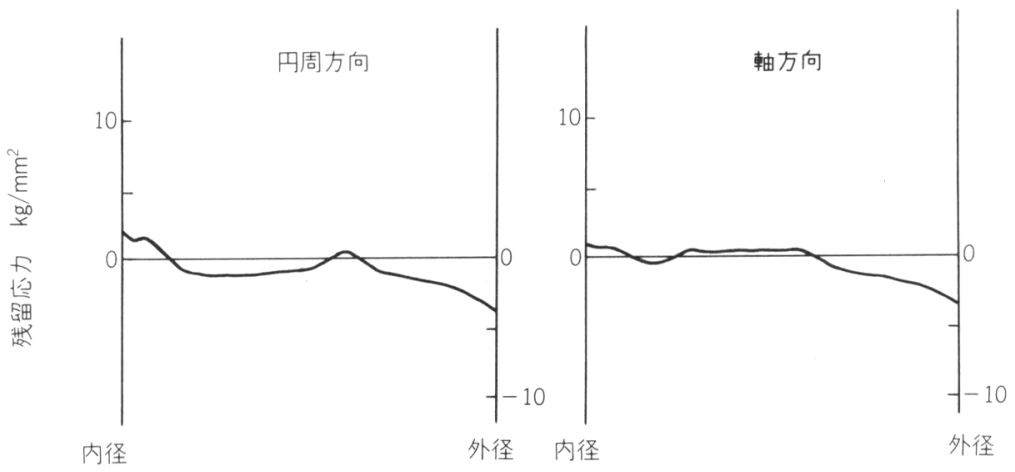

図 6 ミニチュアサクションロール材のザックス法による残留応力分布 


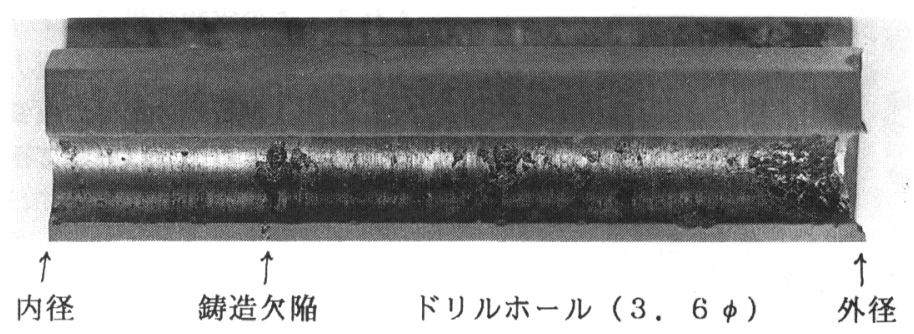

写真 $213 \mathrm{Cr}$ 系折損鋳造ロールのドリルホールの内面

\begin{tabular}{|c|c|c|c|c|c|c|}
\hline 1 & & C & $\mathrm{Cr}$ & $\mathrm{Ni}$ & Mo & $\mathrm{Cu}$ \\
\hline 鍛 & 13Cr系 & 0.09 & 12.35 & 0.53 & 2.31 & $\cdots$ \\
\hline 造 & $18 \mathrm{Cr}$ 系 & 0.06 & 18.40 & 4.58 & 2.17 & ---- \\
\hline 材 & 21Cr系 & 0.07 & 21.90 & 5.12 & 3.18 & 0.95 \\
\hline 鋳 & $13 \mathrm{Cr}$ 系 & 0.08 & 11.40 & 0.21 & 0.34 & --- \\
\hline 造 & 25Cr系 & 0.07 & 26.10 & 4.00 & 0.73 & 0.48 \\
\hline 材 & 21Cr系 & 0.06 & 20.34 & 6.24 & $\cdots$ & 2.51 \\
\hline
\end{tabular}

\begin{tabular}{|c|}
\hline 試験片 \\
\hline $15 \times 15 \times 20$ \\
\hline 腐食液 \\
\hline $5 \%$ 沸騰硫酸 \\
\hline 腐食時間 \\
\hline 6 時間 \\
\hline
\end{tabular}

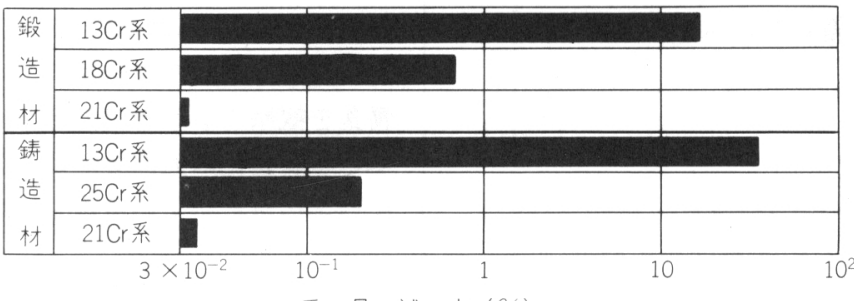

重量減少 $(\%)$

図 7 各素材の 5 \%硫酸による腐食減量の比較 (JIS G 0591)

\section{3. 良快削性の新材質の開発 ${ }^{12)}$}

\section{1 新材質の耐食性}

図 7 は JIS G 0591 による 5\%硫酸の沸騰溶液を用い た腐食試験の結果である。比較材として，これまでサ クションロールとして使用されている各種素材を用い た。新しく開発した素材は鍛造による $21 \mathrm{Cr}$ 系と表示 したものである。耐腐食性は合金成分の Cr， Ni，Mo 量が多いほど良好であり，粒界の腐食が支配的となる この試験方法では, $\mathrm{Cu}$ に上る効果か極めて大きいこと が分る。この試験から得られた耐食性の傾向は白水で の耐食性をよく表現していると言える。

\section{2 機械加工性の比較検討}

図8はドリル穴を明ける際, ドリル先端に発生する トルク（回転反力）およびスライト（前進反力）を測 定し，切削抵抗を判定するための試験装置である。

機械加工性を比較する場合, 基準として利用すると 最も良く理解できる材料としては $13 \mathrm{Cr}$ 系の鋳造材が ある。この材料を使用したサクションロールは最も多 く，ドリリング条件はほとんどの機械でマスターされ

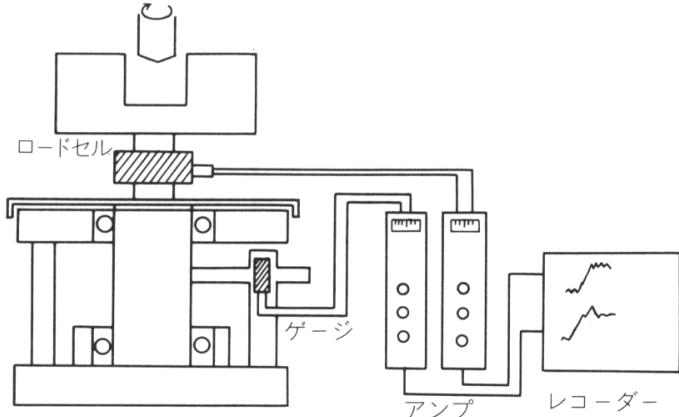

図８トルクおよびスラスト測定のための試験 装置

ていると判断できるからである。

図 9 は $550 \mathrm{rpm}, 0.05 \mathrm{~mm} / \mathrm{rev}$.の加工速度で $8 \mathrm{~mm}$ ドリルにより穴明けした場合の加工抵抗が，標準とな る鋳造材の $13 \mathrm{Cr}$, あるいは鍛造材の $18 \mathrm{Cr}$ 系 2 相合金 とどのように異なるかを測定した数例を示したもので ある。トルクおよびスラスト力は低い值ほど切削抵抗 が低いのでその平均值が低いことが望ましい。一方， 刃先に振動が発生するような状況は刃先の劣化の原因 


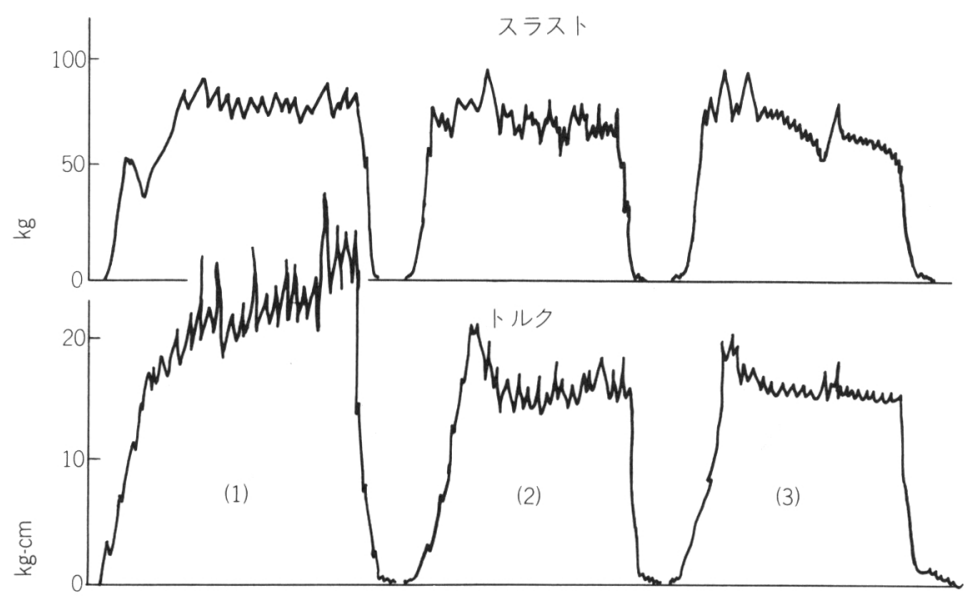

図 9 試験装置によるトルクとスラストの測定例

1 ：鋳造 $13 \mathrm{Cr}$ 素材の場合

$2 ：$ 鍛造 2 相合金の場合

$3:$ 鍛造新材料の場合
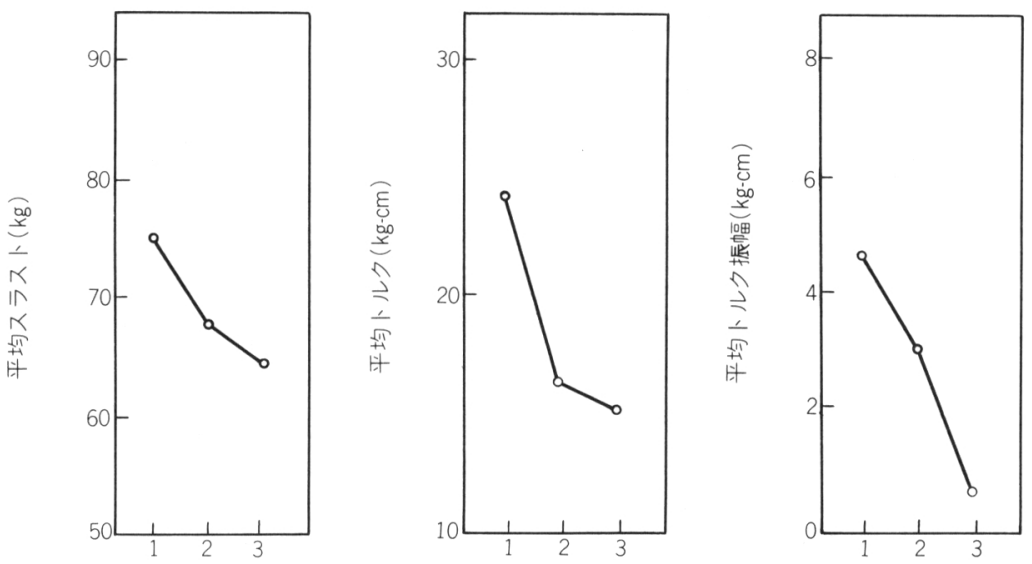

試料番号

図 $10500 \mathrm{rpm}$ の場合の鋳造材と鋳造材の切削特性

となるため望ましくない。

スラストおよびトルクの変化を示す測定曲線にはノ コギリ刃状の応力振幅が見られるが, これは刃先近傍 で加工硬化が起き，次第に加工抵抗が増加していく様 子を示したもので，この応力振幅が少ない材料ほど良 い加工性を示す材料である。

図 10 は各材質の $550 \mathrm{rpm}$ の場合の切削抵抗をまと めたもので, 平均スラスト, 平均トルクおよび平均ト ルク振幅を見ることで素材の切削特性が表わせること を示している。残留応力を低減させる熱処理のできる 従来の $18 \mathrm{Cr}$ 系の 2 相合金の場合にも新材料に匹敵す る加工性を示しており, 機械加工する際の条件設定を
表 2 ドリリングの条件

\begin{tabular}{c|l}
\hline ドリルの名称 & $\begin{array}{l}\text { Tin Coated Twist Drill, Cobalt } \\
\text { Twist Drill }\end{array}$ \\
\hline ドリル径 & $6 \mathrm{~mm} \phi$ \\
\hline 切削送り & $0.05 \mathrm{~mm} / \mathrm{rev}$. \\
\hline 切削速度 & $\begin{array}{l}224 \mathrm{rpm}, 450 \mathrm{rpm}, 710 \mathrm{rpm}, \\
1,120 \mathrm{rpm} \text { の } 4 \text { 段階 }\end{array}$ \\
\hline 切削深さ & $20 \mathrm{~mm}$ \\
\hline その他の条件 & 無潤滑 \\
\hline
\end{tabular}



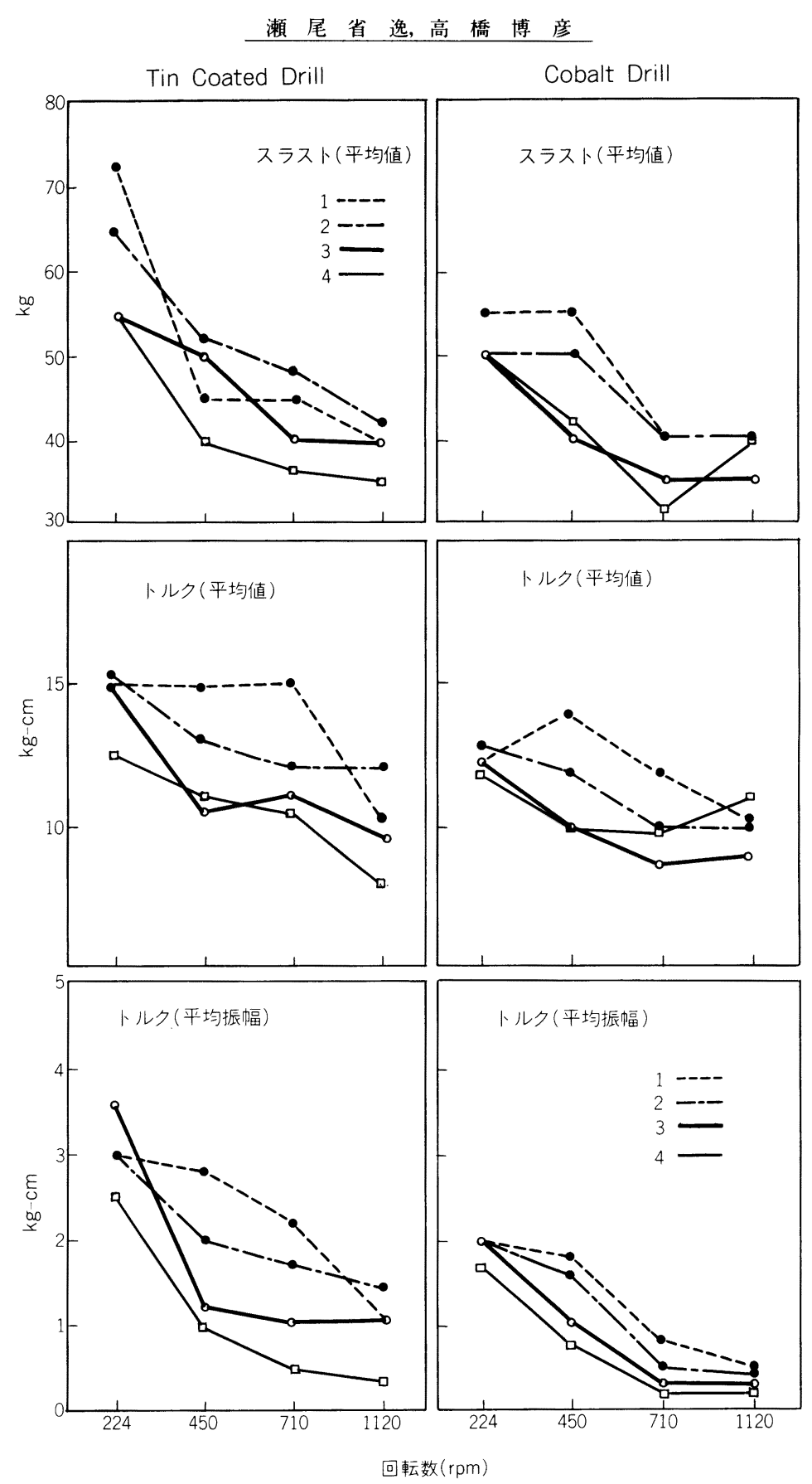

図 11 各種素材の加工条件による加工性の比較

$1:$ 鋳造材の $13 \mathrm{Cr}$ 系

$2:$ 鍛造材の $13 \mathrm{Cr}$ 系

3 : 鍛造材の 2 相合金 (18 Cr-4 Ni 系)

$4:$ 鍛造材の 2 相系新材質 $(21 \mathrm{Cr}-6 \mathrm{Ni}$ 系 $)$

することで極めて良好なパターンを得ることができる。は従来の 2 相合金よりも優れた加工性を示している。

図 11 は加工条件を変化させた場合, 各材質の切削特

性がどのように推移するかを比較したもので, 新材質
なお，ドリリング条件は表 2 のおりである。

これらの試験により，材料の被削性がドリルにどの 
ような応力を与えるかを判定し，材料の総合的な切削 特性を迅速に判断することができる。

したがって, 潤滑液を使用する害際の加工条件を一 義的に決定することはできないが，ここに得られた結 果は材料の被切削性が明らかに加工速度により異なり， どの材料も比較的高速の加工条件において, ドリルの 寿命が伸びることを予想させる結果を得た。さらに特 徵的な事実として, どの材質においても, 鍛造材はド リルに対して抵抗が少ないことが分った。

\section{3 新材質の機械的性質}

表 3 は良加工性である新材料の室温における機械的 性質を示したものである。この材料は 2 相合金の特徴 である低い降伏比（降伏応力／抗張力）を示すが, 良 好な耐食性のため腐食疲労強度は極めて高い值を示し ている。

\section{4 新材質の顕微鏡組織}

写真 3 に特に快削性を重視した素材の組織写真を示 した。微細な析出相をわずかに含んだ”フエライト+ オーステナイト”組織よりなる 2 相合金である。組織 は鍛造されているため, パイプの長手方向に伸びてい るが, 組織の分布状態は場所的な依存性がなく, どの 位置をとらえても同様の組織が見られる。この様に組 織はどこをとらえても均一であるという特性は鍛造材 の特徴で, 鋳造材では凝固組織であるデンドライトの ために組織が粗く, 成分の偏析が存在する。鍛造材で は機械的にデンドライト組織が破壊されるため, 鋳造 材の弱点がすべて改善されることになる。

\section{4. 熱処理残留応力とサクションロールの 残留応力}

素材であるパイプ材が加工されてサクションロール として製造され，抄紙機にセットされた後，折損事故 を起こす場合の原因について考察する。製造順に要因 を並べると次の通りであり, 加工条件をいかに重要な 要因として取り扱わなければならないかということが 理解できる。

（1）材料欠陥（パイプ素材固有の特性）

(2) 熱処理残留応力

（3）ドリリングによる応力の開放（加工性が悪いと パターンの乱れの原因となる)

(4) サクションロール素材の腐食疲労強度

(5) サクションロールに作用する応力 (設計応力)

（6）使用条件による腐食雲囲気（材料の耐食性）

この 6 項目のうち, 材料欠陥, 材料の耐食性, 腐食 疲労強度および熱処理残留応力は素材メ一カーが制御 できる項目であるが, ドリリングの際に発生する現象 の制御と使用雲囲気についてはユーザーの方々の努力 に期待するものである。

ドリリングが熱処理残留応力を $1 / 5$ 以下にするとい う事実は, 不均一な加工が行われると, 応力緩和のば らつきが起こるためロールの異常变形が起きることを 示している。さらに, 加工性が悪い素材をドリリング すると,ドリルの損傷が激しく, 応力緩和のばらつき はさらに増幅される。また，ドリルの進む方向性に対 しても材料の加工性は影響を与えるため, 難加工材で

表 3 新材質の機械的性質

\begin{tabular}{c|c|c|c|c|c}
\hline $\begin{array}{c}0.2 \% \text { 耐力 } \\
\mathrm{kg} / \mathrm{mm}^{2}\end{array}$ & $\begin{array}{c}\text { 抗張力 } \\
\mathrm{kg} / \mathrm{mm}^{2}\end{array}$ & $\begin{array}{c}\text { 伸 び } \\
\%\end{array}$ & $\begin{array}{c}\text { 硬 度 } \\
\mathrm{BHN}\end{array}$ & $\begin{array}{c}\text { 衝 撃 值 } \\
\mathrm{kg} \cdot \mathrm{m} / \mathrm{cm}^{2}\end{array}$ & $\begin{array}{c}\text { 腐 食 疲 労強度 } \\
\mathrm{kg} / \mathrm{mm}^{2}\left(10^{9}, \text { TAPPI I }\right)\end{array}$ \\
\hline 44.6 & 73.5 & 24.7 & 217 & 6.3 & 16.7 \\
\hline
\end{tabular}
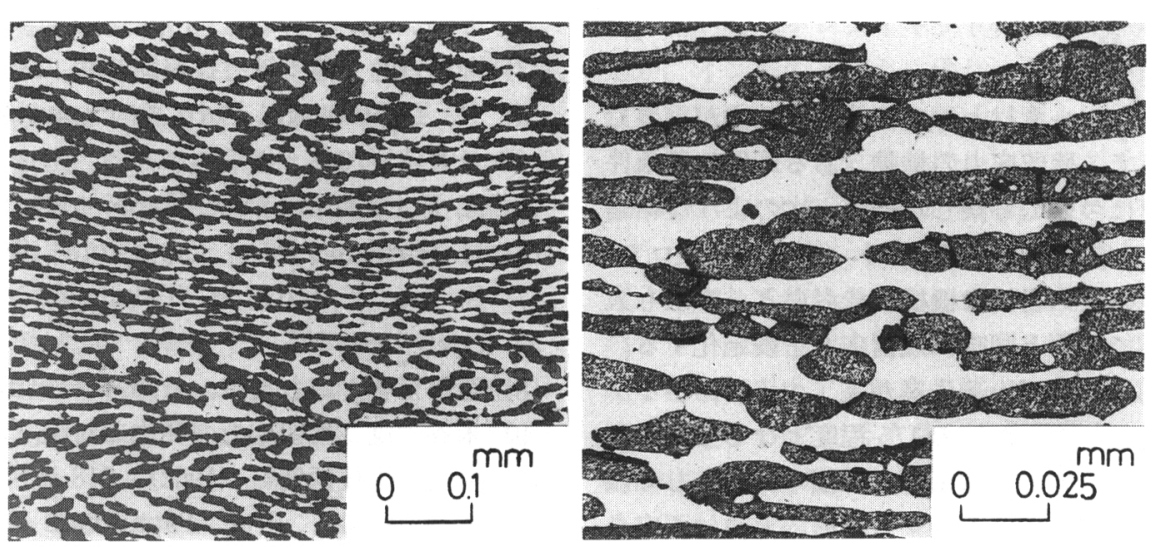

写真 3 加工性に優れた材料の顕微鏡組織 $(\times 86, \times 345)$ 


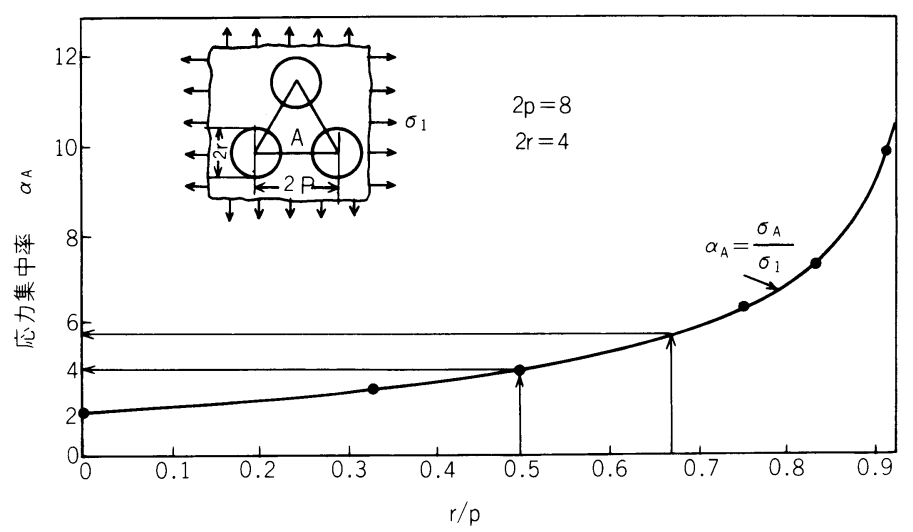

図 12 三角形モデルにおける開口率と応力集中係数の関係(8)

はパターンの乱れが発生し易い。

腐食疲労強度はドリルホールが正常に分布する場合 を想定しているが，パターンが乱れている部分では応 力集中係数が大きく変化する。図 12 は三角形モデルに おいて, 開口率の変化が応力集中係数に対してどのよ うに変化するかを示したものであるが，穴が接近した 場合, 応力集中係数の变化を予測する事ができる ${ }^{8)}$ 。例 えば，曲げ応力が $2 \mathrm{~kg} / \mathrm{mm}^{2}$ として設計されたサク ションロールにおいては, 正三角形モデルではドリル ホール最短距離の方向で最大発生応力となり, 約 $20 \%$ の開口率では $8 \mathrm{~kg} / \mathrm{mm}^{2}$ であるが $\left(\alpha_{\mathrm{A}}=0.5\right)$, 正三角 形の頂点の位置から $2 \mathrm{~mm}$ 外れるとその応力は 10.8 $\mathrm{kg} / \mathrm{mm}^{2}$ となり, $13 \mathrm{Cr}$ 系では疲労破壊が起こりうる ことになる。

この場合, 残留応力は素材の状態では $3 \mathrm{~kg} / \mathrm{mm}^{2}$ で あり, ドリル加工後では $0.6 \mathrm{~kg} / \mathrm{mm}^{2} て ゙$, 疲労強度の $5 \%$ 程度にしかならず, 疲労破壊にはほとんど関与せ ず，加工むらによる応力集中の効果が材料の寿命を決 定したことになり，材料の加工性がいかに大切かが分 る。

\section{5. 結 論}

サクションロール素材として何故, 加工性が重要で あるかについて, 残留応力の挙動, あるいは加工条件 と素材の関連について考察した結果, 次のような結論 を得た。

（1）加工性の良い材料は機械製造者にとって最も大 切な性質であると同時に残留応力を安定化する。

(2) 残留応力は Drilling 作業が完了すると，パイプ 素材に残留していた値の $1 / 5$ 程度となることが測 定された。このことにより，折損の原因として残 留応力が作用しているとする残留応力説は否定さ れる。
（3）穴明けの加工条件が不適切な場合，発熱による 残留応力の局部的な増加あるいは減少が起こり, パイプの変形が発生することになる。

（4）耐食性を改善するということは $\mathrm{Cr}, \mathrm{Ni}$ 合金量 の增加により達成されるため, 通常は加工性が劣 化するが，新しく開発した析出硬化型の耐食合金 は優れた加工性を示す。

(5) $13 \mathrm{Cr}$ 系のステンレス鋼は 2 相あるいはオース テナイト系の物より“ねばさ”の点で劣るが加工 性においては優れ, 腐食性の低い白水では加工性 に優れた欠陥のない $13 \mathrm{Cr}$ 系の鍛造材が最も優れ た材料であると言える。

(6) Drillingにより残留応力の開放があるため, 素 材における応力値がそのまま使用上のトラブルの 原因になることはないが, 素材加工上の留意点と して考慮されなければならない。

\section{文献}

1) A. GARNER : Pulp \& Paper CANADA 3 (1985) 81

2) W. S. Butterfield : Tappi sep. (1982) 139

3）瀬尾省逸 他：紙八技協誌，39（1985）1124

4) R. Thompson : Pulp \& Paper Magazin 72 (1971), 70

5) A. P. Castillo : Proc. Tappi conf. 1984, 601

6) H. Hiraishi : Proc. Tappi conf. 1984, 611

7) S. Seo, Y. Sato, H. Takahashi : Proc. Tappi conf. 1984, 197

8）西田正孝：応力集中, (1969) 森出出版

9）米谷 茂: 残留応力の発生と対策, (1979) 養賢堂

10）切削加工技術便覧（1962），518 日刊工業

11) R. A. Yeske : Proc. Tappi conf. 1987, 17

12）瀬尾省逸 他：特許出願中, 昭 61-146071 